\title{
Perbandingan Kualitas Fermentasi Biji Kakao dengan Penambahan Kultur Campur dan Kultur Tunggal Lactobacillus brevis
}

\section{Comparison of the Quality of Cocoa Bean Fermentation with the Addition of Mixed and Single Cultures of Lactobacillus brevis}

\author{
Rannes ${ }^{1}$, Andree Wijaya Setiawan ${ }^{1}$, Yoga Aji Handoko ${ }^{1 凶}$ \\ ${ }^{1}$ Program Studi Agroteknologi, Fakultas Pertanian dan Bisnis, Universitas Kristen Satya Wacana \\ Komunikasi Penulis, email: yoga.handoko@staff.uksw.edu \\ DOI:http://dx.doi.org/10.23960/jtep-l.v10i4.537-547
}

Naskah ini diterima pada 28 November 2021; revisi pada 19 Desember 2021;

disetujui untuk dipublikasikan pada 25 Desember 2021

\begin{abstract}
Cocoa beans are one of the plants whose processing process is through fermentation to get quality cocoa beans. The purpose of this study was to determine the quality of fermented cocoa beans with the addition of mixed cultures of Saccharomyces cereviseae, Lactobacillus plantarum, Lactobacillus fermentum, Acetobacter orientalis, Acetobacter tropicalis, and single culture of Lactobacillus brevis and determine the best quality of fermented cocoa beans between mixed culture and single culture of Lactobacillus brevis. This study used a randomized block design with 7 treatments and 4 replications. Each treatment was carried out by adding a single culture and mixed culture in the logarithmic growth phase with a culture concentration of $5 \%, 10 \%$, and $15 \%$, and as a control, fermentation was conditioned to occur naturally. Observation parameters are $\mathrm{pH}$, temperature, water content, yield, total fat content, total sugar content, lactic acid content, cut test, and organoleptic. The results of the fermentation showed that a good quality was obtained in the P5 treatment (addition of 10\% mixed culture) which was perfectly fermented 94\% and entered the quality class 1 of SNI 2323:2008.
\end{abstract}

Keywords: cocoa, fermentation, mixed culture, single culture, Lactobacillus brevis

\begin{abstract}
ABSTRAK
Biji kakao adalah salah satu tanaman yang proses pengolahannya melalui fermentasi dengan tujuan untuk mendapatkan kualitas biji kakao bermutu. Tujuan penelitian ini yaitu untuk mengetahui mutu biji kakao fermentasi dengan penambahan biakan kultur campur Saccharomyces cereviseae, Lactobacillus plantarum, Lactobacillus fermentum, Acetobacter orientalis, Acetobacter tropicalis dan kultur tunggal Lactobacillus brevis serta menentukan kualitas hasil fermentasi terbaik biji kakao antara kultur campur dan kultur tunggal Lactobacillus brevis. Penelitian ini menggunakan rancangan acak kelompok (RAK) dengan 7 perlakuan dan 4 kali ulangan. Setiap perlakuan dilakukan dengan penambahan kultur tunggal dan kultur campur pada fase pertumbuhan logaritmik dengan konsentrasi kultur $5 \%, 10 \%$, dan $15 \%$, serta sebagai kontrol tidak dikondisikan terjadi fermentasi secara alami. Parameter pengamatan yaitu $\mathrm{pH}$, suhu, kadar air, rendemen, kadar lemak total, kadar gula total, kadar asam laktat, cut test dan organoleptik. Hasil fermentasi yang memiliki kualitas baik diperoleh pada perlakuan P5 (penambahan kultur campur 10\%) yaitu terfermentasi sempurna 94\% dan masuk kelas mutu 1 SNI 2323:2008.
\end{abstract}

Kata kunci: fermentasi, kakao, kultur campur, kultur tunggal, Lactobacillus brevis

\section{PENDAHULUAN}

Kakao merupakan salah satu komoditas perkebunan yang memiliki peran sangat penting bagi perekonomian nasional, pengembangan wilayah bahkan pengembangan agroindustri (Kementerian Pertanian, 2015). Menurut Rachmatullah et al. (2021) produksi kakao
Indonesia mencapai 590.684 ton dan pada tahun 2018 mencapai 593.833 ton dengan luas lahan 1,72 juta ha, di mana sebagian besar $(88,48 \%)$ dikelola oleh perkebunan rakyat, $(5,53 \%)$ dikelola oleh perkebunan besar negara dan $(5,59 \%)$ dikelola oleh perkebunan swasta (Outlook Kakao, 2017). 
Rachmatullah et al. (2021) menyatakan kakao di Indonesia masih menghadapi berbagai masalah komplek yaitu produktivitas kebun yang masih rendah akibat serangan hama, penyakit busuk buah maupun penanganan pascapanen. Terdapat dua sistem pascapanen pada biji kakao yaitu biji kakao difermentasi dan biji kakao tanpa fermentasi. Menurut Badan Pendataan Statistik (2017), biji kakao kering tanpa fermentasi \pm 5.450 .000 ton dan biji kakao difermentasi \pm 385.000 ton. Biji kakao tanpa fermentasi, diolah melalui pencucian biji kakao menggunakan air demi mengurangi pulp dan dilanjutkan pengeringan. Sedangkan biji kakao fermentasi, biji kakao dimasukkan dalam kotak kayu, ditutup daun pisang dan didiamkan 3-5 hari tanpa penambahan mikroba setelah itu dilanjutkan pengeringan. Proses diatas menyebabkan biji kakao yang dihasilkan mempunyai mutu yang kurang baik (Apriyanto et al. 2016)

Proses fermentasi pada biji kakao memiliki peran yang sangat penting karena fermentasi membantu menghilangkan pulp dan memberikan rasa, aroma cokelat. Dengan bantuan mikroba pulp biji kakao dalam bentuk gula dan polisakarida akan dirombak sehingga menghasilkan metabolit yang dapat memberi aroma coklat (Ho et al., 2014). Apabila biji kakao tidak difermentasi maka cita rasa dan aroma tidak terbentuk serta menyebabkan biji rasa pahit dan sepat. Fermentasi biji kakao dengan penambahan khamir pada penelitian Apriyanto et al. (2016), kandungan gula reduksi, asam dan etanol rendah. Hal ini disebabkan karena pada penambahan mikroba dilakukan secara bertahap sehingga kinerja asam laktat kurang optimal. Maka dari itu, diperlukan trobosan baru dalam melakukan fermentasi biji kakao yaitu penambahan 3 (tiga) jenis mikroba dalam satu wadah yaitu (1) yeast berperan untuk mendegradasi pulp menjadi etanol, (2) bakteri asam laktat berperan mengubah gula dan asam sitrat, (3) asam asetat berperan untuk mengoksidasi etanol menjadi asam asetat (Usman et al., 2018).

Proses fermentasi, mikroba akan perombakan gula menjadi asam organik sehingga suhu meningkat dan proses fermentasi berlangsung lebih cepat 5-6 hari. Penambahan lebih dari satu jenis mikrob disebut kultur campur dan penambahan satu jenis mikrob disebut monokultur atau kultur tunggal (Apriyanto et al., 2016). Fermentasi kultur tunggal menggunakan bakteri Lactocacillus brevis yang merupakan bakteri asam laktat heterofermentatif yang mampu memproduksi asam laktat sehingga meningkatkan total asam, $\mathrm{CO}_{2}$, dapat melakukan fermentasi pada semua jenis karbohidrat, dan mampu membunuh kapang yang tumbuh dalam proses fermentasi (DeVuyst dan Weckx, 2016). Berdasarkan latar belakang tersebut, tujuan dari penelitian ini yaitu untuk mengetahui perbandingan hasil fermentasi biji kakao antara kultur campur dan kultur tunggal Lactobacillus brevis serta menentukan kualitas hasil fermentasi terbaik biji kakao antara kultur campur dan kultur tunggal Lactobacillus brevis.

\section{BAHAN DAN METODE}

Penelitian ini dilaksanakan di Laboratorium Pascapanen, Fakultas Pertanian dan Bisnis, Universitas Kristen Satya Wacana, Salatiga pada bulan April sampai September 2021. Bahan utama yang digunakan dalam penelitian ini yaitu biji kakao jenis Sulawesi. Bahan untuk pembuatan mikroba yaitu media PDA (potato dextrose agar), media MRSB (deMann rogosa sharpe broth), YPG (pepton yeast glukosa), dengan mikroba Saccharomyces cereviseae, Lactobacillus brevis, Lactobacillus plantarum, Lactobacillus fermentum, Acetobacter orientalis, Acetobacter tropicalis. Bahan yang digunakan untuk analisis yaitu etanol $96 \%$, akuades, $\mathrm{NaOH}$ $0,1 \mathrm{~N}, \mathrm{PP}$ (phenolphthalein) 0,1\%, glukosa, reagen Nelson, Arsenomolibdat, N-Heksana teknis, $\mathrm{H}_{2} \mathrm{SO}_{4}$ (asam sulfat) 0,1M. Sedangkan alat yang digunakan besek (anyaman bambu) sebagai wadah fermentasi, Hanna meter HI9124, moisture analyzer Shimadzu moc63u, inkubator, enkas, spektrofotometer UV-1280 Shimadzu, hotplate, autoklaf, erlenmeyer, beaker glass, labu takar $100 \mathrm{~mL}$, statif, klem, buret, kuvet, corong, kertas saring, soxhlet, serangkaian alat destilasi.

\subsection{Tahapan Penelitian}

Rancangan percobaan yang akan digunakan dalam penelitian ini adalah RAK (Rancangan Acak Kelompok) dengan faktor kosentrasi mikroba menggunakan 4 kali ulangan. P (tanpa kultur), P1 (kultur tunggal 5\%), P2 (kultur 
tunggal 10\%), P3 (kultur tunggal 15\%), P4 (kultur campur 5\%), P5 (kultur campur 10\%) dan P6 (kultur campur 15\%). Data yang diperoleh dianalisis menggunakan sidik ragam (ANOVA) dan apabila ada pengaruh maka akan dilanjutkan dengan menggunakan uji DMRT (Duncan) dengan taraf nyata 95\% kepercayaan.

\subsection{Prosedur Penelitian}

Tahap pembuatan kultur mikroba yaitu membuat media MRSB untuk bakteri L. brevis, L. plantarum, L. fermentum, media PYG untuk bakteri $A$. orientalis, $A$. tropicalis, dan khamir $S$. cereviseae. Kemudian tiap media dilarutkan dalam akuades sesuai kebutuhan, Lalu dipanaskan menggunakan hotplate dan dilanjutkan dengan sterilisasi menggunakan autoklaf. Setelah media dingin, dilakukan inokulasi kultur 2-3 ose pada media cair dan didiamkan selama 7 jam dalam inkubator. Biji kakao yang akan difermentasi dimasukkan dalam besek sebanyak 500 g, kemudian kultur mikroba dituang sesuai perlakuan. Perlakuan kultur mikroba dalam penelitian ini, diaplikasikan sebagai berikut: konsentrasi 5\% ditambahkan $25 \mathrm{~mL}$ kultur mikrob, konsentasi $10 \%$ ditambahkan $50 \mathrm{~mL}$, dan konsentrasi $15 \%$ ditambahkan $75 \mathrm{~mL}$. Proses fermentasi berlangsung selama 6 hari dalam inkubator pada suhu $43^{\circ} \mathrm{C}$ untuk kultur tunggal dan suhu $32^{\circ} \mathrm{C}$ untuk kultur campur pada 3 hari pertama, kemudian pada hari ke 4-5 suhu kultur campur dinaikkan menjadi $43^{\circ} \mathrm{C}$ dan hari terakhir diturunkan menjadi $32^{\circ} \mathrm{C}$. Selama proses fermentasi berlangsung dilakukan pengamatan suhu dan $\mathrm{pH}$. Setelah proses fermentasi selesai, kemudian biji kakao dikeringkan dengan sinar matahari dan inkubator pada suhu $45^{\circ} \mathrm{C}$. Mengeringkan biji kakao menggunakan sinar matahari dan inkubator hanya memerlukan waktu 3 hari. Parameter pengamatan meliputi: $\mathrm{pH}$, suhu, kadar air, rendemen, kadar lemak total, kadar gula total, asam laktat, cut test dan uji organoleptic.

\subsection{Pengukuran Parameter}

\subsubsection{Derajat Keasaman dengan Menggunakan Instrumentasi Hanna HI9124}

Prinsip pengukuran $\mathrm{pH}$ adalah hasil pengukuran terhadap konsentrasi ion hidrogen bebas yang menyatakan ukuran keasaman atau pun alkalinitas suatu larutan dengan menggunakan $\mathrm{pH}$ meter. Cara pengukuran $\mathrm{pH}$ yaitu $10 \mathrm{~g}$ biji kakao fermentasi dimasukan dalam beaker glass kemudian tambahkan aquades $10 \mathrm{~mL}$, lalu dihomogenkan. Selanjutnya elektroda dicelupkan dalam sampel untuk mengetahui $\mathrm{pH}$ sampel.

\subsubsection{Suhu dengan Menggunakan Instrumentasi Hanna HI9124}

Pengukuran suhu dilakukan selama proses fermentasi berlangsung yaitu selama 6 hari dengan 3-5 menit supaya nilai stabil Pengukuran suhu menggunakan termometer dengan cara menancapkan ujung termometer ditengahtengah wadah setiap kali pengukuran dilakukan (Amin, 2005).

\subsubsection{Kadar Lemak Total dengan Metode Soxhlet}

Pengujian lemak (Pargiyanti, 2019) dilakukan pada sampel biji kakao kering yang telah dihaluskan. Sampel sebanyak $2 \mathrm{~g}$ dibungkus dalam kertas saring dan dimasukkan dalam Soxhlet dan ditambahkan pengekstrak NHeksana sebanyak $200 \mathrm{~mL}$ kemudian didiamkan selama 6 jam. Setelah itu, hasil ektrasi didestilasi untuk memisahkan heksan sama lemak kakao. Setelah proses destilasi, lemak kakao di oven pada suhu $81^{\circ} \mathrm{C}$ selama 1 jam. Setelah 1 jam kadar lemak ditimbang, dan hasil yang didapatkan dimasukkan dalam persamaan:

$$
\text { Kadar Lemak (\%) }=\frac{\text { Botol isi }- \text { botol } \text { kosong }}{\text { Berat sampel }} 100 \%
$$

\subsubsection{Kadar Total Gula dengan Metode Nelson-Somogyi}

Pengujian total gula (Ariefta et al., 2016) menggunakan sampel yang telah dihaluskan sebanyak 1gram dimasukkan dalam labu takar $100 \mathrm{~mL}$ dan ditambahkan aquades sebanyak $100 \mathrm{ml}$. kemudian saring menggunakan kertas saring, ambil filtrat $1 \mathrm{~mL}$ tambahkan reagen Nelson dan akuades 7 mL. Kemudian panaskan dengan hotplate selama 20 menit. Setelah dingin tambahkan reagen Arsenomolibdat sebanyak 1 mL kemudian lakukan pengukuran absorbansi pada Panjang gelombang $540 \mathrm{~nm}$.

\subsubsection{Asam Laktat dengan Metode Titrimetri} Pengujian asam laktat (Sukendar et al., 2019) menggunakan sampel sebanyak 5 gram 
dimasukkan dalam labu takar $100 \mathrm{ml}$ dan ditambahkan akuades sebanyak $100 \mathrm{ml}$. kemudian disaring, filtrat diambil senyak $10 \mathrm{ml}$ tambahkan 2 tetes PP $0,1 \mathrm{~N}$ lalu titrasi dengan $\mathrm{NAOH} 0,1 \%$ hingga warna menjadi merah muda. Hasil yang diperoleh dimasukkan dalam persamaan:

Kadar Asam Laktat $=\frac{V \mathrm{NaOH} \times \mathrm{N} \mathrm{NaOH} \times 90}{\text { Berat sampel } \times 1000} 100 \%$

\subsubsection{Kadar Air dengan Menggunakan Intrumentasi Moisture Analyzer Shimadzu MOC63U}

Pengukuran kadar air dilakukan dengan mengikuti petunjuk manual intrumentasi moisture analyzer Shimadzu moc63u. Sampel sebanyak $5 \mathrm{~g}$ ditimbang. Sampel dimasukkan di piring aluminium dan diletakkan di atas permukaan moisture analyzer, kemudian klik start untuk memulai pengukuran. Dalam beberapa menit kadar air dari sampel akan terbaca pada alat tersebut.

\subsubsection{Uji Cut test}

Pengujian pada cut test (Aryani, 2018) dilakukan pada biji kakao yang telah kering menggunakan pisau atau cutter. Biji kakao yang diuji senyak 50 biji, yang dipotong menjadi 2 bagian secara melintang hingga nibs kakao terlihat. Uji cut test bertujuan untuk melihat persentase keberhasilan proses fermentasi. Tingkat keberhasilan fermentasi (TKF) kemudian dimasukkan dalam persamaan:

$$
T K F=\frac{\text { biji terfermentasi sempurna }}{\text { berat sampel }} 100 \%
$$

\subsubsection{Uji Organoleptik}

Pengujian organoleptik (Hayati et al., 2012) dilakukan dengan uji skala hedonik menggunakan 20 orang panelis tidak terlatih dengan parameter pengujian warna, rasa, tekstur dan aroma. Panelis diminta memberilakn nilai berdasarkan tingkat kesukaan, dengan skor: $1=$ sangat tidak suka, 2 = tidak suka, $3=$ agak suka, $4=$ suka, $5=$ sangat suka.

\section{HASIL DAN PEMBAHASAN}

\subsection{Suhu Fermentasi Biji Kakao}

Fermentasi berlangsung dengan bantuan mikroba. Pengukuran suhu dalam proses fermentasi biji kakao berfungsi untuk mengetahui kinerja mikrob. Ketersediaan oksigen yang cukup dapat membantu proses oksidasi perombakan senyawa gula dalam pulp sehingga suhu lingkungan sekitar meningkat. Suhu merupakan salah satu faktor yang mempengaruhi keberhasilan fermentasi biji kakao (Ariyanti, 2017).

Gambar 1 menunjukkan suhu awal pada perlakuan P1-P3 $35^{\circ} \mathrm{C}$ dan suhu P4-P6 $32^{\circ} \mathrm{C}$, kemudian perlakuan P1-P3 mengalami kenaikkan suhu pada hari ke 2-4 yaitu pada suhu $40^{\circ} \mathrm{C}$ dan turun pada hari ke 6 yaitu $35^{\circ} \mathrm{C}$. Sedangkan perlakuan P4-P6 suhu naik ke 35$40^{\circ} \mathrm{C}$ dan mengalami penurunan pada hari ke 6 pada suhu $35^{\circ} \mathrm{C}$. Suhu yang dihasilkan pada gambar 1 berbeda dengan perlakuan suhu yang di set awal. Suhu awal setiap perlakuan memiliki rata-rata $32-36^{\circ} \mathrm{C}$. Menurut Apriyanto et al., (2016), adanya reaksi enzimatis dalam proses fermentasi biji kakao oleh mikrob dalam merombak alkohol dan asam serta pada waktu bersamaan akan melepaskan panas sehingga, menyebabkan suhu mengalami peningkatan.

Perubahan suhu menunjukkan aktivitas mikrob S. cerevisiae pada suhu $37^{\circ} \mathrm{C}$ di hari pertama hingga kedua, bakteri asam laktat pada $43{ }^{\circ} \mathrm{C}$ di hari ke- 2 dan ke- 5 , serta bakteri asam asetat pada suhu $37^{\circ} \mathrm{C}$ di hari terakhir. Tabel 2 memperlihatkan bahwa hari ke-1, ke- 4 dan ke6 setiap perlakuan tidak berbeda nyata, Hari ke2 perlakuan P3 memiliki kenaikan suhu sangat nyata dari pada perlakuan lainnya, namun tidak berbeda nyata dengan perlakuan P, P4, P5 dan P6. Hari ke-3 perlakuan P1 dan P2 memiliki kenaikkan suhu berbeda sangat nyata dengan perlakuan lainnya namun tidak berbeda nyata dengan perlakuan P5 dan p6. Pada hari ke-5 perlakuan P6 mengalami kenaikan suhu sangat berbeda nyata dengan perlakuan $\mathrm{P}$, namun tidak berbeda nyata pada perlakuan lainnya. Adanya perbedaan suhu setiap perlakuan, menyebabkan biji kakao yang dihasilkan juga berbeda. Menurut Ariyanti (2017), peningkatan suhu pada proses fermentasi tergantung dari aktivitas mikroba dalam merombak gula menjadi alkohol serta asam-asam organik, seperti asam laktat dan asam asetat yang merupakan reaksi yang dapat mengeluarkan enargi panas, sehingga suhu meningkat. 


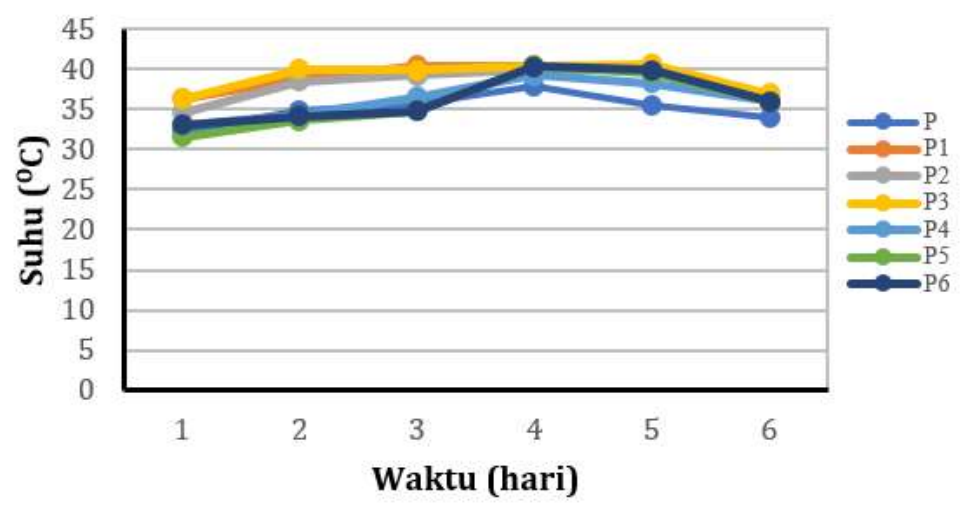

Gambar 1. Dinamika Suhu Fermentasi Biji Kakao

(Keterangan: P (kontrol), P1 (kultur tungal 5\%), P2 (kultur tunggal 10\%), P3 (kultur tunggal 15\%), P4 (kultur campur 5\%), P5 (kultur campur 10\%), P6 (kultur campur 15\%))

Tabel 1. Dinamika Suhu Selama Fermentasi Melalui Analisis DMRT

\begin{tabular}{ccccccc}
\hline \multirow{2}{*}{ Perlakuan } & \multicolumn{7}{c}{ Hari } \\
\cline { 2 - 7 } & $\mathbf{1}$ & $\mathbf{2}$ & $\mathbf{3}$ & $\mathbf{4}$ & $\mathbf{5}$ & $\mathbf{6}$ \\
\hline P & 31,2 & $34,5 \mathrm{c}$ & $36,5 \mathrm{abc}$ & 38,5 & $36 \mathrm{~b}$ & 34,5 \\
P1 & 34,5 & $37,8 \mathrm{abc}$ & $40,5 \mathrm{a}$ & 40 & $40,5 \mathrm{ab}$ & 35,5 \\
P2 & 32,8 & $38,5 \mathrm{ab}$ & $39,5 \mathrm{a}$ & 40 & $39,7 \mathrm{ab}$ & 35,8 \\
P3 & 33,9 & $40,1 \mathrm{a}$ & $39 \mathrm{ab}$ & 40,5 & $39,6 \mathrm{ab}$ & 36,5 \\
P4 & 32,2 & $34,8 \mathrm{bc}$ & $37,9 \mathrm{abc}$ & 39,5 & $37,8 \mathrm{ab}$ & 34,3 \\
P5 & 30,8 & $34,2 \mathrm{c}$ & $35 \mathrm{bc}$ & 40,3 & $39,5 \mathrm{ab}$ & 35,7 \\
P6 & 31,9 & $34,1 \mathrm{c}$ & $34,6 \mathrm{c}$ & 40 & $41 \mathrm{a}$ & 36,2 \\
\hline
\end{tabular}

Keterangan: P (kontrol), P1 (kultur tungal 5\%), P2 (kultur tunggal 10\%), P3 (kultur tunggal 15\%), P4 (kultur campur 5\%), P5 (kultur campur 10\%), P6 (kultur campur 15\%). Angka yang diikuti huruf sama dalam suatu kolom yang sama menunjukkan tidak berbeda nyata menurut uji DMRT $5 \%$.

\section{2. pH Fermentasi Biji Kakao}

pH (derajat keasaman) merupakan salah satu indikator yang sangat penting. Pegukuran pH bertujuan mengetahui tingkat keasaman yang berasal dari proses perombakan asam organik hasil metabolisme pada saat fermentasi berlangsung (Utami, 2018).

Gambar 2 terlihat dinamika $\mathrm{pH}$ fermentasi pada biji kakao setiap perlakuan mengalami penurunan hingga hari ke-3, namun meningkat pada hari ke-4 dan ke-6. Penurunan $\mathrm{pH}$ fermentasi disebabkan adanya kandungan sejumlah asam dalam pulp biji kakao yang dirombak oleh bakteri asam laktat dengan aktivitas pektiolitik yang dapat menurunkan kandungan pH (Apriyanto, 2016). Sedangkan pada hari ke-4 dan ke-6, pH mengalami peningkatan ini yang disebabkan aktivitas bakteri asam laktat menurun, seiiring dengan bakteri asam asetat mengubah gula menjadi asam asetat dan karbondioksida. Aktivitas perombakan tersebut menyebabkan kandungan pulp akan menurun kuantitasnya sehingga terjadi peningkatan $\mathrm{pH}$ dan kenaikan suhu (Utami, 2018).

Tabel 2 menunjukkan pH pada biji kakao selama proses fermentasi berlangsung. Pada hari ke-1 dan ke- 6 tidak berbeda nyata antar perlakuan. Hari ke-2 P3 memiliki pH sangat berbeda nyata dengan perlakuan $\mathrm{P} 1$, namun tidak berbeda nyata dengan perlakuan lainnya. Hari ke-3 perlakuan P3 sangat berbeda nyata dengan P5 dan P6, namun tidak berbeda nyata dengan perlakuan lainnya. Hari ke-4 pH perlakuan P2 dan P3 sangat berbeda nyata dengan perlakuan P5 dan P6, namun tidak berbeda nyata dengan perlakuan lainnya. Hari ke-5 pH perlakuan P3 sangat berbeda nyata dengan perlakuan P, P5 dan P6, namun tidak berbeda nyata dengan perlakuan lainnya. pH mengalami peningkatan karena belum terjadi proses difusi asam dalam biji sehingga nilai pH pada biji kakao tinggi (Utami, 2018). 


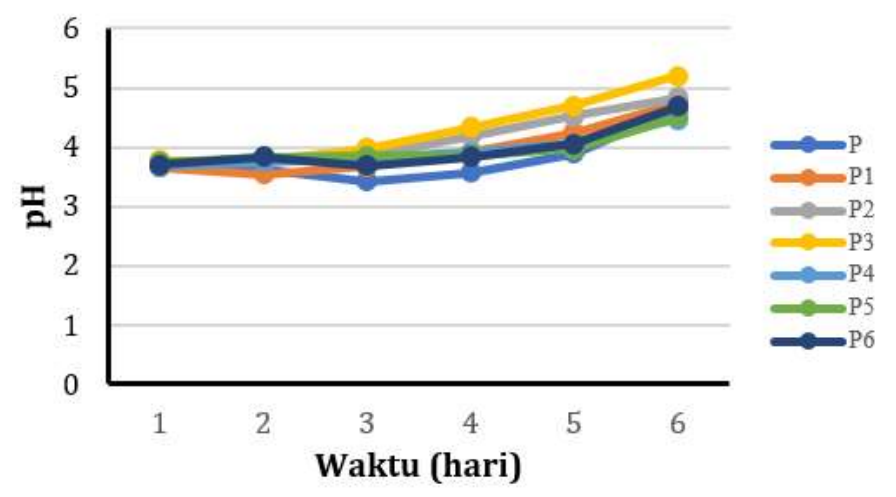

Gambar 2. Dinamika pH Fermentasi Biji Kakao

(Keterangan: P (kontrol), P1 (kultur tungal 5\%), P2 (kultur tunggal 10\%), P3 (kultur tunggal 15\%), P4 (kultur campur 5\%), P5 (kultur campur 10\%), P6 (kultur campur 15\%))

Tabel 2. Dinamika pH Selama Fermentasi Melalui Analisis DMRT

\begin{tabular}{ccccccc}
\hline \multirow{2}{*}{ Perlakuan } & \multicolumn{7}{c}{ Hari } \\
\cline { 2 - 7 } & $\mathbf{1}$ & $\mathbf{2}$ & $\mathbf{3}$ & $\mathbf{4}$ & $\mathbf{5}$ & $\mathbf{6}$ \\
\hline P & 3,62 & $3,73 \mathrm{ab}$ & $3,52 \mathrm{ab}$ & $3,64 \mathrm{~b}$ & $3,85 \mathrm{~b}$ & 4,36 \\
P1 & 3,62 & $3,69 \mathrm{~b}$ & $3,82 \mathrm{ab}$ & $4,10 \mathrm{ab}$ & $4,54 \mathrm{ab}$ & 5,03 \\
P2 & 3,68 & $3,77 \mathrm{ab}$ & $3,96 \mathrm{ab}$ & $4,33 \mathrm{a}$ & $4,64 \mathrm{ab}$ & 4,95 \\
P3 & 3,67 & $3,85 \mathrm{a}$ & $3,99 \mathrm{a}$ & $4,47 \mathrm{a}$ & $5,05 \mathrm{a}$ & 5,41 \\
P4 & 3,69 & $3,78 \mathrm{ab}$ & $3,84 \mathrm{ab}$ & $3,95 \mathrm{ab}$ & $4,15 \mathrm{ab}$ & 4,61 \\
P5 & 3,7 & $3,77 \mathrm{ab}$ & $3,41 \mathrm{~b}$ & $3,69 \mathrm{~b}$ & $3,78 \mathrm{~b}$ & 4,26 \\
P6 & 3,58 & $3,74 \mathrm{ab}$ & $3,50 \mathrm{~b}$ & $3,71 \mathrm{~b}$ & $3,96 \mathrm{~b}$ & 4,60 \\
\hline
\end{tabular}

Keterangan: P (kontrol), P1 (kultur tungal 5\%), P2 (kultur tunggal 10\%), P3 (kultur tunggal 15\%), P4 (kultur campur 5\%), P5 (kultur campur 10\%), P6 (kultur campur 15\%). Angka yang diikuti huruf sama dalam suatu kolom yang sama menunjukkan tidak berbeda nyata menurut uji DMRT 5\%

\subsection{Rendemen, Kadar Air, dan Cut Test Biji Kakao}

Salah satu parameter penting untuk uji biji kakao yaitu mengetahui nilai rendemen, bertujuan untuk mengetahui kualitas biji kakao yang dihasilkan. Nilai rendemen didapat dari input dibagi output kemudian dikalikan 100\%. Kandungan rendemen mengalami penurunan jika komponen dalam bahan yang hilang banyak. Sebaliknya, kandungan rendemen tinggi maka, komponen yang hilang sedikit (Arief, 2011).

Nilai rendemen yang didapat memiliki kandungan yang berbeda-beda. Bila dibandingkan dengan rendemen yang diberi perlakuan kultur, rendemen tanpa penambahan kultur lebih rendah dari pada yang diberi kultur. Rendemen tanpa penambahan kultur 36,6\% dan rendemen tertinggi pada perlakuan P2 (penambahan kultur tunggal 10\%) yaitu 40,2\%. Tingginya kandungan rendemen akan berpengaruh pada kadar air biji kakao karena selama proses fermentasi meyebabkan penurunan kadar air pada biji kakao sehingga hal tersebut juga dapat menurunkan nilai rendemen pada biji kakao. Adanya aktivitas enzim dan mikroba dalam proses fermentasi menyebabkan pulp hancur menjadi cairan. Hancurnya air keluar secara bebas karena poripori telah pecah (Kumalasari, 2012). Nilai kadar air yang diperoleh pada tiap perlakuan bervariasi. Kadar air terendah diperoleh dari perlakuan tanpa penambahan kultur yaitu 6,2\% dan nilai kadar air tertinggi diperoleh dari perlakuan dengan penambahan kultur campur konsentrasi 15\% (P6) yaitu 7,0\%. Hasil rendemen dan kadar air mempengaruhi hasil akhir biji kakao yaitu nilai cut test (Afoakwa et al., 2014).

Untuk mengetahui keberhasilan fermentasi biji kakao dari segi warna yang dihasilkan maka 
Tabel 3. Rendemen, Kadar Air, dan Cut test Hasil Fermentasi

\begin{tabular}{cccc}
\hline Perlakuan & Rendemen (\%) & Kadar air (\%) & Cut test (\%) \\
\hline P & 36,6 & 6,2 & $79 \mathrm{~b}$ \\
P1 & 38,9 & 6,3 & $85 \mathrm{ab}$ \\
P2 & 40,2 & 6,3 & $89 \mathrm{ab}$ \\
P3 & 38,6 & 6,9 & $82 \mathrm{ab}$ \\
P4 & 38,8 & 6,5 & $88 \mathrm{ab}$ \\
P5 & 38,6 & 6,9 & $94 \mathrm{a}$ \\
P6 & 38,7 & 7,0 & $90 \mathrm{ab}$ \\
\hline
\end{tabular}

Keterangan: P (kontrol), P1 (kultur tungal 5\%), P2 (kultur tunggal 10\%), P3 (kultur tunggal 15\%), P4 (kultur campur 5\%), P5 (kultur campur 10\%), P6 (kultur campur 15\%). Angka yang diikuti huruf sama dalam suatu kolom yang sama menunjukkan tidak berbeda nyata menurut uji DMRT 5\%

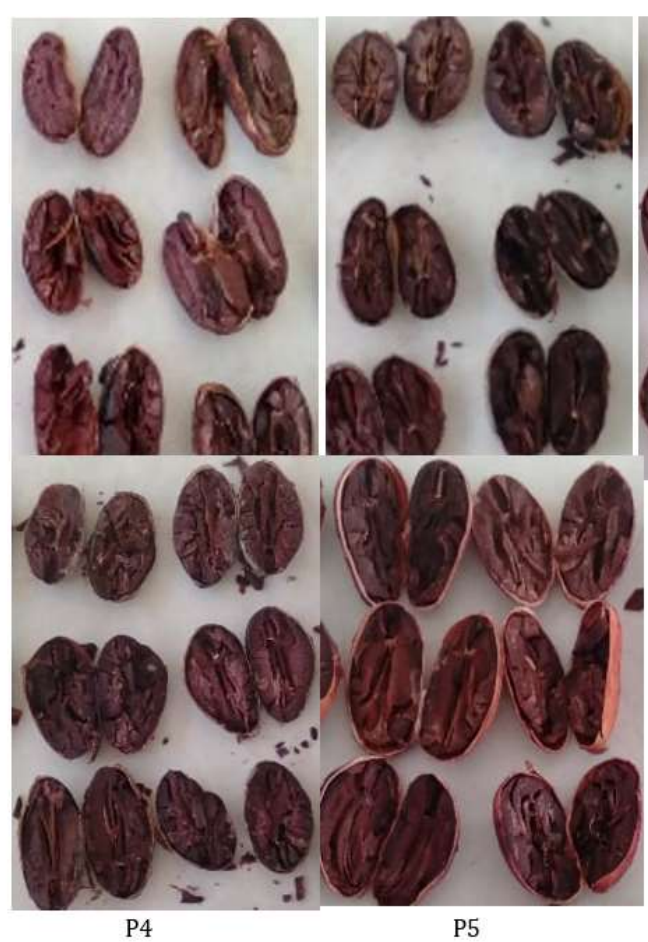

P2

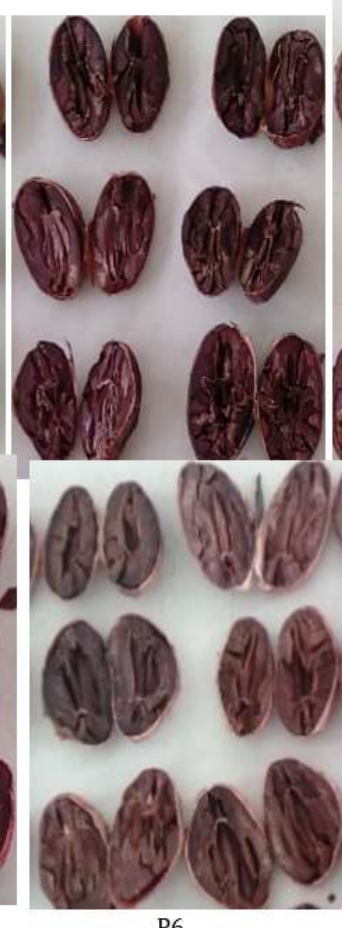

P3

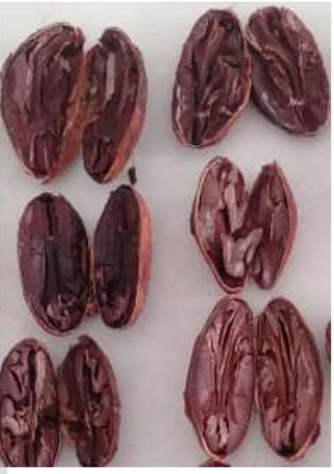

Gambar 3. Uji Cut Test P (Tanpa Kultur), P1 (Kultur Tunggal 5\%), P2 (Kultur Tunggal 10\%), P3 (Kultur Tunggal 15\%), P4 (Kultur Campur 5\%), P2 (Kultur Campur 10\%) Dan P6 (Kultur Campur $15 \%)$

dilakukan uji cut test. Fermentasi dikatakan berhasil apabila biji kakao yang didapatkan terfermentasi sempurna yaitu biji kakao berwarna coklat secara keseluruhan biji sedangkan biji kakao tidak terfermentasi (slaty) akan berberwarna ungu (Sukander, 2019). Hasil cut test yang dilakukan dalam penelitian ini, diproleh perlakuan penambahan kultur campur konsentrasi 10\% (P5) biji kakao terfermentasi sempurna secara maksimal yaitu $94 \%$ dan perlakuan tanpa penambahan kultur (P) terfermentasi sedang yaitu 79\%. Perlakuan P5 terfermentasi sempurna yaitu $94 \%$ memiliki nilai rendemen 38,6\%. Rendahnya rendemen yang dihasilkan karena adanya komponen bahan yang hilang selama proses fermentasi biji kakao. Hasil analisis sidik ragam perlakuan kultur campur konsentrasi 10\% (P5) berbeda nyata dengan P (tanpa penambahan mikrob) dan tidak berbeda nyata dengan perlakuan lainnya.

\subsection{Kandungan Gula Reduksi, Asam Laktat, dan Lemak}

Pengujian kandungan gula reduksi pada biji kakao perlu dilakukan untuk mengetahui citarasa biji kakao karena gula merupakan bahan 
baku pembentukan etanol. Gula dalam pulp dirombak oleh pektin dengan bantuan enzim pektinase dipecah menjadi alkohol, lalu enzim pektinase dirombak menjadi asam asetat. perombakan gula dilakukan oleh khamir (Apriyanto et al., 2016).

Hasil kadar gula reduksi yang didapat terlihat dalam Tabel 4 diperoleh bervariasi. Pada Tabel 4, hasil analisa gula pada penambahan kultur campur konsentrasi 10\% (P5) memiliki nilai lebih tinggi yaitu $5,29 \mathrm{mg} / \mathrm{ml}$ sedangkan nilai terendah terdapat pada perlakuan penambahan kultur tunggal konsentrasi 5\% (P1) yaitu 4,32 $\mathrm{mg} / \mathrm{ml}$. Kandungan gula meningkat karena adanya Saccharomyces cerevisae melalui kinerja enzim invertase yang merombak sukrosa menjadi gula reduksi dapat berjalan dengan baik (Ariefta et al., 2016). Sedangkan kandungan gula reduksi rendah diakibatkan karena pada perlakuan tanpa kultur tidak ditambahkan Saccharomyces cerevisae, sehingga penguraian yang terjadi terbatas (Kuswawati, 2017).

Proses fermentasi pada biji kakao akan merusak pulp dan menghasilkan alkohol dan asam organik selanjutnya akan dirombak menjadi asetat oleh bakteri asam asetat. Hasil analisa total asam tertinggi terdapat pada perlakuan penambahan kultur campur konsentrasi 10\% (P5) yaitu 0,67\% dengan bantuan Lactobacillus plantarum, Lactobacillus brevis dan Lactobacillus fermentum dengan bantuan enzim pektinase sehingga menghasilkan asam maksimal sedangkan hasil asam yang rendah terdapat pada perlakuan penambahan kultur tunggal dengan konsentrasi 5\% (P1) dengan bantuan Lactobacillus brevis dengan bantuan enzim pektinase sehingga asam kurang maksimal. Hasil sidik ragam $\mathrm{P} 5$ berpengaruh nyata terhadap P1, P2 dan tidak berpengaruh nyata terhadap perlakuan lainnya. Kandungan asam meningkat dari asam organik seperti asam laktat dan asam asetat. Total asam yang rendah juga disebabkan asam larut dalam cairan pulp karena adanya proses depolimerisasi yang terus berlangsung (Nirwana, 2017).

Dari hasil perombakan gula akan terbentuk lemak pada biji kakao. Lemak pada biji kakao diperoleh dari aktivitas perombakan senyawa gula, polifenol dan protein dengan bantuan saccharomyces cerevisiae dan bakteri asam laktat Lactobacillus plantarum, Lactobacillus brevis dan Lactobacillus fermentum dengan bantuan enzim pektinase. Lemak merupakan produk hasil pengepresan kakao massa (liquor) pada biji kakao. Hasil analisa lemak biji kakao tertinggi pada perlakuan penambahan kultur tunggal konsentrasi 15\% (P3) yaitu 51,95\% sedangkan kandungan lemak terendah pada perlakuan penambahan kultur campur konsentrasi 15\% (P6). Peningkatan jumlah lemak disebabkan oleh rendahnya kadar air karena mengalami penurunan selama proses fermentasi sehingga berpengaruh terhadap jumlah rendemen dan lemak serta sebaliknya jumlah lemak yang rendah disebabkan nilai rendemen dan kadar air tinggi. Kadar lemak relative meningkat, karena lemak bersifat larut dalam air dan dapat terurai menjadi komponen-kompenen yang lebih kecil sehingga berdifusi keluar dari keping biji (Hayati et al., 2012).

\subsection{Organoleptik Biji Kakao Fermentasi}

Uji organoleptik pada penelitian ini diuji dengan

Tabel 4. Kandungan Gula Reduksi, Total Asam, dan Lemak Hasil Fermentasi

\begin{tabular}{cccc}
\hline Perlakuan & $\begin{array}{c}\text { Gula Reduksi } \\
\text { (mg/mL) }\end{array}$ & $\begin{array}{c}\text { Total Asam } \\
\text { (\%) }\end{array}$ & $\begin{array}{c}\text { Lemak } \\
\text { (\%) }\end{array}$ \\
\hline P & $5,08 \mathrm{a}$ & $0,45 \mathrm{abc}$ & 49,45 \\
P1 & $4,32 \mathrm{c}$ & $0,24 \mathrm{c}$ & 50,25 \\
P2 & $4,90 \mathrm{ab}$ & $0,39 \mathrm{c}$ & 50,02 \\
P3 & $4,49 \mathrm{bc}$ & $0,41 \mathrm{bc}$ & 51,95 \\
P4 & $4,81 \mathrm{abc}$ & $0,46 \mathrm{abc}$ & 48,50 \\
P5 & $5,29 \mathrm{a}$ & $0,67 \mathrm{a}$ & 50,45 \\
P6 & $5,10 \mathrm{a}$ & $0,65 \mathrm{ab}$ & 45,75 \\
\hline
\end{tabular}

Keterangan: P (kontrol), P1 (kultur tungal 5\%), P2 (kultur tunggal 10\%), P3 (kultur tunggal 15\%), P4 (kultur campur 5\%), P5 (kultur campur 10\%), P6 (kultur campur 15\%). Angka yang diikuti huruf sama dalam suatu kolom yang sama menunjukkan tidak berbeda nyata menurut uji DMRT $5 \%$ 
Tabel 5. Uji Organoleptik

\begin{tabular}{ccccccccc}
\hline Perlakuan & Tekstur & NI (\%) & Warna & NI (\%) & Aroma & NI (\%) & Rasa & NI (\%) \\
\hline P & 70 & S & 67 & S & 64 & S & 60 & S \\
P1 & 65 & S & 78 & SS & 64 & S & 63 & S \\
P2 & 73 & S & 78 & SS & 63 & S & 63 & S \\
P3 & 66 & S & 80 & SS & 62 & S & 67 & S \\
P4 & 66 & S & 80 & SS & 69 & S & 65 & S \\
P5 & 66 & S & 75 & SS & 63 & S & 67 & S \\
P6 & 67 & S & 81 & SS & 65 & S & 63 & S \\
\hline
\end{tabular}

Keterangan: P (tanpa kultur), P1 (kultur tunggal 5\%), P2 (kultur tunggal 10\%), P3 (kultur tunggal 15\%), P4 (kultur campur 5\%), P5 (kultur campur 10\%), P6 (kultur campur 15\%), NI (nilai index), SS (sangat suka) dan S (suka).

metode skala hedonik, menggunakan parameter tekstur, rasa, aroma dan warna (Marpaung dan Putri, 2019). Warna terbentuk dari lama pengeringan dan waktu fermentasi, pada saat proses pengeringan terjadi penguraian senyawa polifenol dengan bantuan polifinol oksidase sehingga dapat menghasilkan warna coklat pada biji kakao. Perubahan tersebut ditandai dengan berkurangnya warna ungu pada biji kakao. Hasil uji organoleptik parameter warna pada biji kakao hasil fermentasi diperoleh kategori sangat suka pada setiap perlakuan penambahan kultur campur 15\% (P6) yaitu 81\%, berarti penguraian yang terjadi selama proses fermentasi oleh bakteri asam laktat Lactobacillus plantarum, Lactobacillus brevis dan Lactobacillus fermentum dan bakteri asam asetat Acetobacter orientalis dan Acetobacter tropicalis berjalan maksimal. Warna yang baik dihasilkan pada perlakuan penambahan kultur campur pada perlakuan tersebut biji terfermentasi sempurna berwarna coklat, bagian tengah berongga dan biji kering. Warna coklat terjadi karena pengaruh oleh proses fermentasi dan pengeringan yang tepat. Tekstur pada biji kakao juga dipengaruhi pengeringan dan proses fermentasi. Selama proses fermentasi berlangsung terjadi penguraian senyawa fenol, protein dan sukrosa pada biji kakao sehingga menyebabkan tekstur pada biji kakao berongga. Bila biji kakao terfermentasi sempurna akan memiliki tekstur mudah pecah atau renyah hal ini disebabkan karena proses pengeringan. Hasil terbaik diperoleh pada perlakuan penambahan kultur tungal 10\% (P2) yaitu 73\%.

Parameter rasa pada biji kakao terbentuk pada proses fermentasi melalui perombakan gula, protein dan polifenol dengan bantuan enzim pembentuk rasa pada biji kakao. Jika semua senyawa dapat terurai selama proses fermentasi maka akan terbentuk cita rasa aroma khas coklat seperti golongan ester, pirazin, perol dan furan. Uji yang diperoleh pada parameter rasa yaitu adanya rasa pahit, asam dan sepat. Rasa pahit disebabkan oleh adanya senyawa theobromine. Menurut Yusianto et al. (1995), rasa pahit pada biji kakao karena adanya kandungan antosianin dan theobromine yang tinggi. Rasa asam disebabkan adanya asam-asam organik seperti asam asetat hasil perombakan alkohol oleh L.brevis, L.plantarun dan L.fermentum dalam biji kakao selama proses fermentasi. Sedangkan rasa sepat disebabkan adanya kandungan antosianoin yang tinggi. Adanya kandungan asam asetat yang tinggi sehingga rasa biji kakao asam. Hasil rasa terbaik diperoleh pada perlakuan penambahan kultur tunggal 15\% (P3) yaitu $67 \%$ dan penambahan kultur campur $10 \%$ (P2) yaitu 67\%.

Aroma dalam biji kakao terbentuk karena proses fermentasi melalui perombakan peptida dan karbohidrat sehingga dihasilkan senyawa volatil dengan reaksi gugus karbosil dan amina. Namun aroma khas biji kakao terbantuk dari peptida hidrofobik, asam-asam hidrofobik serta gula pereduksi. Uji parameter aroma yang diperoleh pada biji kakao yaitu aroma asam, kopi sangrai dan tape. Hasil parameter aroma terbaik terdapat pada perlakuan penambahan kultur campur 5\% (P4) yaitu 69\%. Parameter aroma, rasa dan tekstur masuk kategori disukai oleh panelis, hal ini diartikan kinerja dari kultur yang digunakan tidak bekerja maksimal (Marpaung, 2019). Namun ketegori warna terbentuk maksimal karena masuk kategori sangat disukai oleh panelis. bantuan polifenol oksidase sehingga 
menghasilkan warna coklat dan rasa pada biji kakao fermentasi (Hayati et al., 2012).

\section{KESIMPULAN}

Berdasarkan hasil analisis biji kakao yang dilakukan dalam penelitian ini, dengan perbandingan penggunaan kultur tunggal dan campur pada biji kakao, kandungan gula total tertinggi pada perlakuan P5 yaitu $5,29 \mathrm{mg} / \mathrm{mL}$, kandungan total asam tertinggi pada perlakuan P5 yaitu 0,67 dan kandungan lemak tertinggi pada perlakuan P3 yaitu 51,95\%, sedangkan hasil terbaik terdapat pada perlakuan P5 karena terfermentasi sempurna yaitu $94 \%$ melalui uji cut test dan masuk mutu I dalam SNI 2323:2008.

\section{DAFTAR PUSTAKA}

Afoakwa, E.O., Budu, A.S., Mensah-Brown, H. dan Felix, J. 2014. Changes in biochemical and physico-chemical qualities during drying of pulp preconditioned and fermented cocoa (Theobroma cacao) beans. Journal of Nutritional Health and Food Science. 2: 1-8.

Apriyanto, M., Sutardi, Supriyanto dan Harmayani, E. 2016. Study on effect of fermentation to quality parameter of cocoa bean Indonesia. Asian Journal Diary and Food Research. 35(2): 160-163.

Arief, R. W., dan Asnawi, R. 2011. Karakterisasi sifat fisik dan kimia beberapa jenis biji kakao Lindak di Lampung. Journal of Industrial and Beverage Crops. 2(3):325330.

Ariefta, G, A. Ganda, P dan Dewi, A. 2016. Pengaruh penambahan tape ragi dan waktu fermentasi terhadap karakteristik pulp biji kakao. Jurnal Rekayasa dan Manajemen Agroindustri. 4(2):42-52.

Ariyanti, M. 2017. Karakteristik mutu biji kakao (Theobroma cacao L) dengan perlakuan waktu fermentasi berdasar SNI 23232008. Jurnal Industri Hasil Perkebunan.
12(1):34-42. http://dx.doi.org/10.33104/ jihp.v12i1.2757

Aryani, N.A., Yulianti, N. L., dan Arda, G. 2018. Karakteristik biji kakao hasil fermentasi kapasitas kecil dengan jenis wadah dan lama fermentasi yang berbeda.Jurnal BETA (Biosistem dan Teknik Pertanian), 6(1): 17-24.

Badan Pendataan Statistik Pertanian Indonesia 2017. Statistik Pertanian 2017. Kementerian Pertanian Republik Indonesia, Jakarta.

DeVuyst, L., dan Weckx, S. 2016. The cocoa bean fermentation process: From ecosystem analysis to starter culture development. Journal of Applied Microbiology. 121(1):517. https://doi.org/10.1111/jam.13045

Hayati, R.,Yusmanizer., Mustafrill, dan Harir, F. 2012. Kajian fermentasi dan suhu pengeringan pada mutu kakao (Theobroma cacao L.). JTEP Jurnal Keteknikan Pertanian, 26(2): 129-132. h ttp s: / / doi.org/10.19028/ jtep.026.2.\%25p

Ho, V.T.T., Zhao, J., dan Fleet, G. 2014. Yeasts are essential for cocoa bean fermentation. International Journal of Food Microbiology, 174: 72-87.

Direktorat Jenderal Perkebunan Kementerian Pertanian. 2015. Ditjen Perkebunan Dukung Tingkatkan Mutu Biji Kakao. https://ditjenbun.pertanian.go.id/2015/ (akses 21 Desember 2021)

Kumalasari, H. 2012. Validasi Metode Pengukuran Kadar Air Bubuk Perisa Menggunakan Moisture Analyzer Halogen HB43-s sebagai Alternatif Metode Oven dan Karl Fischer. Thesis. Jurusan Teknologi Pertanian, IPB, Bogor.

Kusmawati, W. 2017. Analisis kadar asam asetat dalam media limbah fermentasi biji kakao akibat penambahan konsentrasi Acetobacter Aceti dan waktu inkubasi. 
Jurnal Filsafat, Sains, Teknologi dan Sosial Budaya. 1(23): 70-71. https://doi.org/ 10.33503/paradigma.v23i1.371

Marpaung, R., dan Putri, S.N. 2019. Karakteristik mutu organoleptik olahan coklat dengan lama fermentasi yang berbeda pada biji kakao (Theobroma cacao L.). Jurnal Media Pertanian. 4(2):64

Nirwana, N. 2017. Kajian pengaruh berat biji kakako perkotak dan waktu pengadukan terhadap keberhasilan proses fermentasi. Jurnal Pendidikan Matematika Dan IPA. 8(2):18-30. http://dx.doi.org/10.26418/ jpmipa.v8i2

Outlook Kakao 2017. Outlook Tanaman Pangan 2017: Kementerian Pertanian

Pargiyanti. 2019. Optimasi waktu ekstraksi lemak dengan metode Soxhlet. Indonesian Journal of Laboratiry. 1(2): 29-35

Rachmatullah, D., Desiana N P., Fiki H dan Noor H. 2021. Karakteristik biji kakao (Theobroma cacao L.) hasil fermentasi dengan ukuran wadah berbeda. Jurnal
Viabel Pertanian. 15(1):32-44. https:// doi.org/10.35457/viabelv15i1.1409

Sukendar, N K., Abu B T., Salengke., Adiansyah S., Andi H M dan Andi F. 2019. Perubahan sifat fisiko-kimia selama proses fermentasi biji kakao segar. Journal Canrea. 2(2):104. https://doi.org/ 10.20956/canrea.v2i2.214

Usman N.A, Suradi K dan Gumilar J. 2018. Pengaruh konsentrasi bakteri asam laktat Lactobacillus Plantarum dan Lactobacillus Casei terhadap mutu mikrobiologi dan kimia mayones probiotik. Jurnal Ilmu Ternak. 18(2):7985. https://doi.org/10.24198/jit.v18i2

Utami, R R. 2018. Antioksidan biji kakao: Pengaruh fermentasi dan penyangraian terhadap perubahannya. Jurnal Industri Hasil Perkebunan. 13(2):75-85. http:// dx.doi.org/10.33104/jihp.v13i2.4062

Yusianto, Winarno, H. dan Wahyudi, T. 1995. Mutu dan cita rasa biji kakao. Jurnal Sains, 3(2): 156-163. 